\title{
O coro de Coéforas. alimentar a vingança e partilhar o remorso
}

\author{
The chorus of Choephori: to feed revenge and share remorse \\ Maria de Fátima Silva \\ Centro de Estudos Clássicos e Humanisticos- Universidade de Coimbra, Portugal \\ fanp13@gmail.com \\ iD http://orcid.org/0000-0002-8107-9165
}

\section{Resumo:}

O coro de Coéforas tem sido considerado como um dos exemplos de intervenção dramática mais activa no teatro de Ésquilo. Em primeiro lugar, a sua participação no kommós, juntamente com os filhos de Agamémnon, é determinante para a consciencialização e concretização da vingança. Mas, mesmo quando a acção implica o protagonismo do vingador, Orestes, e o coro se torna sobretudo comentador, os sucessivos estásimos são uma espécie de espelho de cada etapa do difícil processo do matricídio. Até que o remorso se instala, depois de um crime tão desejado, mas tão insuportável...

Palavras-chave: Kommós, Homicídio, Vingança, Justiça, Remorso.

\section{AbStract:}

The chorus of Choephori has been considered as an example of a most active intervention in Aeschylus' theatre. First of all, their participation in the kommós, together with Agamemnon's descendants, is decisive for the awareness and realization of revenge. But even when the action implies the protagonism of the avenger, Orestes, and the chorus becomes above all a commentator, the successive stasima are a kind of mirror of each stage of the difficult process of matricide. Until remorse sets in, after a crime so desired, but so unbearable...

KeYWORDS: Kommós, Homicide, Vengeance, Justice, Remorse.

\section{INTRODUÇÃO}

O simples título por que Ésquilo optou na segunda das peças que integram a Oresteia -Coéforas- põe em relevo o ritual fúnebre que constitui uma parte determinante da acção. Assassinado Agamémnon -o episódio central na primeira tragédia da trilogia-, facilmente o público adivinharia que a intenção do poeta estava agora centrada na homenagem devida ao soberano de Micenas e na vingança da sua honra. Mas sem dúvida, para uma audiência familiarizada com os ritos fúnebres e com o papel que os parentes mais próximos do morto neles tinham, uma curiosidade se impunha: como iriam os philoi de Agamémnon prestar-lhe homenagem, principalmente a viúva e assassina? Poderia contar-se com a presença do filho exilado, Orestes, o herdeiro do trono, nos rituais? ${ }^{1}$ Como cumprir os trâmites que a convenção social impunha em tais circunstâncias, dada a anormalidade da situação, quando o falecido -o rei, o marido, o pai- acabava de morrer às mãos da própria mulher?

A resposta dada por Ésquilo a todas estas interrogações não se faz esperar; e é, antes de mais, visual. Orestes está em cena, oculto, temeroso, como alguém que chega, rodeado de insegurança, de um exílio de há anos, para observar a aproximação de um cortejo fúnebre, constituído por servas e por Electra, sua irmã. Uma ausência não deixa de ser gritante, a de Clitemnestra, que as circunstâncias afastam do papel que naturalmente lhe caberia. No centro de todos estes movimentos, como pólo catalizador, está o túmulo de Agamémnon, cuja presença é também latente, para além das fronteiras da vida.

Este é, portanto, um quadro que reproduz a imagem corrente de um ritual fúnebre, sem deixar de conter, em potência, um conjunto de ambiguidades que fazem da homenagem a Agamémnon um episódio particular 
e de grande efeito trágico. O homicídio que legenda aquela morte não se satisfaz com os rituais devidos a todo o ser humano que baixa ao reino de Hades; exige vingança e, com ela, uma emoção que evolui da dor pela perda para a interiorização de uma cólera penalizadora e, por fim, para o golpe da retribuição. Aos filhos da vítima cabe desempenhar o papel de juízes e vingadores; mas, dada a sua fragilidade e hesitação -porque é, afinal, um matricídio o que está em causa-, o coro de cativas, servas fiéis da casa real, terá uma intervenção tanto mais importante na concretização de um acto necessário, ainda que repulsivo e extremo.

\section{O CORO DE COÉFORAS: IDENTIDADE E ACTUAÇÃO}

A própria tradição social, que atribuía a mulheres um papel destacado num contexto de exéquias, determina a natureza feminina do coro, de resto igualmente adequada, dentro da convenção teatral, a cenas de súplica. ${ }^{2}$ A idade - porque se trata de um grupo de mulheres maduras (Coéforas 171) - ${ }^{3}$ acrescenta um contributo oportuno ao papel que lhes está destinado: o de cúmplices leais, mas também de conselheiras e responsáveis pelo impulso que a situação exige, face à imaturidade juvenil que caracteriza os filhos de Agamémnon. Por fim, o estatuto de servas ${ }^{4}$ completa a ideia de que estas mulheres não estão articuladas com nenhuma das personagens da peça em particular, mas com os interesses 'do palácio' no seu todo: associadas à memória do senhor da casa morto à traição, submissas à autoridade ilegítima que agora reina (22), mas sobretudo empenhadas em garantir um futuro de luz e pacificação a uma casa e a uma família penalizadas, de geração em geração, por um destino maldito.

É a Orestes, a personagem prologizousa, que cabe, como espectador oculto perante a aproximação de desconhecidas, registar traços e formular as interrogações que certamente percorrem o auditório; tal como

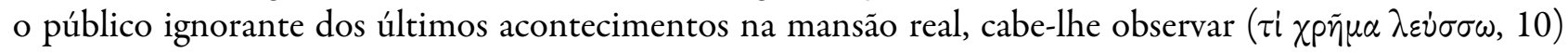
a imagem que lhe é oferecida e interpretá-la, ainda de modo hesitante. Os comentários que tece evoluem

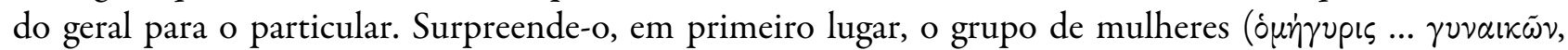
10-11), o efeito de um colectivo coeso produzido pelas recém-chegadas; e logo a marca lutuosa dos "véus fúnebres" ( $\phi \dot{\alpha} \rho \varepsilon \sigma \downarrow \nu \mu \varepsilon \lambda \alpha \gamma \chi i \mu o เ \zeta, 11)$ lhe retém a atenção. Mas por aqui se ficam as certezas, para passarem a dominar as interrogações (12-15): "que sofrimento devo imaginar?" (12); "Será que uma nova dor atingiu o palácio?" (13); "Ou devo entender que estas mulheres trazem ao meu pai as libações que pacificam os mortos?” (14-15). É pela sua boca que a legenda que melhor cabe a estas mulheres - "portadoras de

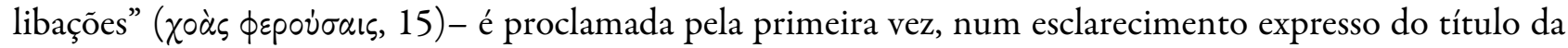
peça. E só depois de comentada esta imagem de conjunto, Orestes regista a presença de Electra (16-18), integrada no grupo de que partilha luto e dor. A Pílades, que em silêncio o acompanha, o filho de Agamémnon sugere que se mantenham ocultos, "de modo a que possa saber com clareza ( $\sigma \alpha \phi \tilde{\omega} \varsigma)$ o que significa aquele

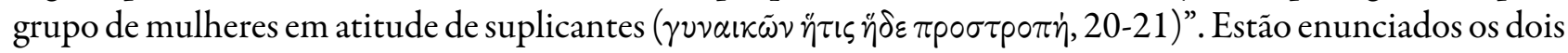
traços identificativos deste coro, os correspondentes a uma atitude de homenagem fúnebre e de súplica, cujo conteúdo é preciso ainda esclarecer plenamente. E assim Orestes delega no párodo a função de complementar as interrogações que formulou. Dos contornos de uma imagem global, passaremos à especificação de um conteúdo, que é também a execução de um ritual.

Para um público da Atenas clássica as atitudes das mulheres que agora se anunciam como "um cortejo

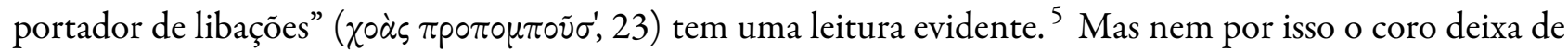
sublinhar, por palavras, os gestos que a função a desempenhar lhes exige: uma marcha solene, acompanhada

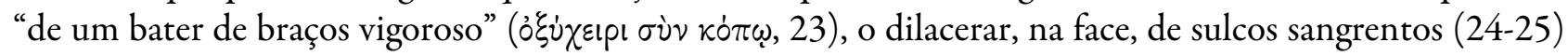
e os soluços que desafogam o coração (26-27). ${ }^{6}$ Numa imagem poética feliz, as mulheres articulam gesto e trajo, fazendo falar as vestes negras que, como elas, "gritam" - "fazendo gritar o linho dos tecidos, a minha dor faz em farrapos os véus que me envolvem o peito” (27-30). A imagem ligeira que Orestes captara num relance de olhos ganha agora um aprofundamento, que as palavras do coro querem expressivo. 
Mas a auto-caracterização feita pelas servas vai mais longe e completa, com uma confissão de sentimentos, a imagem que Orestes deixara muito superficial. A dor é o pano de fundo do seu estado de espírito ("feridas por males a que o riso é estranho", $\dot{\alpha} \gamma \varepsilon \lambda \dot{\alpha} \sigma \tau 0$ เ $\xi \nu \mu \phi o p \alpha i \check{\varsigma} \pi \varepsilon \pi \lambda \lambda \eta \gamma \mu \dot{\varepsilon} \nu \omega \nu, 30-31$ ). A que se associa o medo ( $\phi \dot{\beta} \beta \omega$,

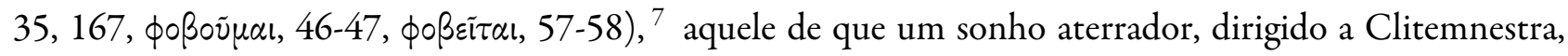
contaminou todo o palácio (36-39). ${ }^{8}$ Do além, os mortos fizeram ouvir o seu desagrado e ira contra os assassinos. Dessa forma, desencadearam o paradoxo subjacente ao que parecia o cumprimento de uma regra comum; a mulher que o ordenou, a viúva, é ímpia ( $\mu^{\prime} i \dot{\alpha} \lambda \lambda_{\varepsilon l} \delta \dot{\sigma} \sigma \theta \varepsilon \circ \varsigma$ $\left.\gamma \nu \nu \dot{\alpha}, 45-46\right)$, como ultrajante é a

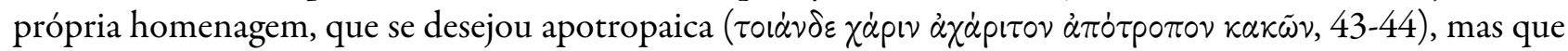
se adivinha punitiva. À partida, portanto, o coro vive no pavor de acontecimentos que apenas se vislumbram, condicionado pela autoridade da rainha -e assassina- e pela exigência legítima da sua vítima; só pouco a pouco as servas se libertam do medo e assumem a determinação, que as leva a apoiar a vingança; partilham assim do crescimento que os filhos de Agamémnon, os vingadores, vão também experimentando. ${ }^{9}$ Mas uma certeza lhes alimenta a esperança: a de que uma Justiça vigilante existe e não deixa sem castigo, mais cedo ou mais tarde, aqueles que prevaricaram (61-65; cf. 295, 383, 650, 935, 1009). Depois de se focar nos culpados, o coro volta-se agora sobre si próprio (દ่uoi, 75). Embora não pertençam à corte que servem e vivam penalizadas pela escravidão e exílio (75-77), os deuses fizeram delas testemunhas e cúmplices dos males que afligem os seus senhores. Não são portanto estranhas, apesar da sua origem e estatuto, aos acontecimentos, vibram com eles; e sob a capa do luto e do temor, vai-se exprimindo um outro sentimento, o do ódio, capaz de alimentar o desejo de vingança que a memória do soberano lhes exige ("é à força que me resigno às ordens -justas ou injustas- dos poderosos e retenho uma ira amarga", 78-83).

A partir desta imagem identificadora, o desenrolar do ritual segue o formato que, segundo Burkert (1985, p. 71), é normal e corresponde a um vulgar sacrifício: primeiro o cortejo, com os vasos, que se dirige ao túmulo; depois o silêncio e a súplica ao morto; por fim, o derramamento das libações, acompanhado de

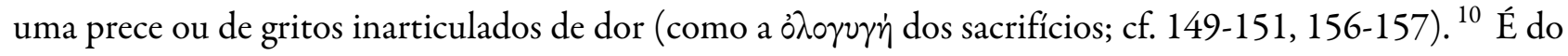
apelo de Electra que depende um passo em frente neste processo, aprofundando a consistência cúmplice do grupo de servas e filhos de Agamémnon (85-86): "uma vez que partilhais comigo este cortejo de súplica,

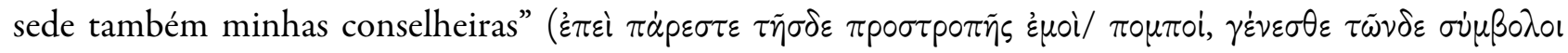

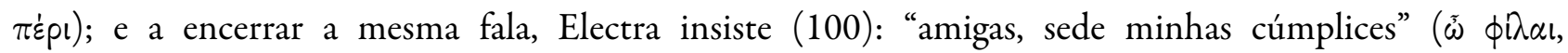
$\mu \varepsilon \tau \alpha i \tau(\alpha \iota) .{ }^{11}$ Porque urge cumprir a segunda fase do ritual, aquela em que os vivos se dirigem aos mortos com as palavras adequadas. ${ }^{12} \mathrm{E}$ tal como antes Orestes acumulara interrogações sobre o sentido do ritual a que assistia, também agora Electra insiste nas perguntas, incapaz de encontrar, nas fórmulas habituais, uma que se ajuste à particularidade da situação (87-88): ${ }^{13}$ "O que dizer ${ }^{14}$ ao derramar $(\tau i$ $\phi \tilde{\omega} \chi \dot{\varepsilon} о v \sigma \alpha)$ estas

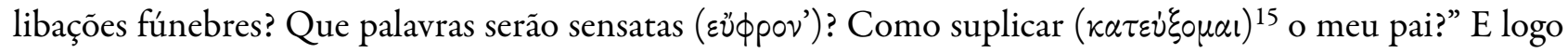
adiantando o paradoxo que impossibilita o cumprimento vulgar do ritual (89-90): "Deverei dizer que ao esposo amado trago oferendas de uma esposa amante, da minha mãe?” Sobre o que deveria ser a fórmula consagrada ( $\dot{\text { s } ~ v o ́ p o s, ~ 91), ~ s q u i l o ~ i n t r o d u z ~ o ~ p a r a d o x o ~ v e r b a l ~ n u m ~ j o g o ~ h a ́ b i l ~ q u e ~ e n t r e l a c ̧ a ~ o ~ m o r t o ~ c o m ~ a ~}$

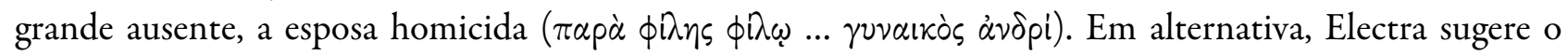
refúgio na ambiguidade, que vem carregada de ironia (94-95), pedindo "a retribuição aos que enviam as oferendas de um dom digno dos crimes cometidos”; ou então, o simples silêncio (96) e a execução de um ritual rápido, mudo -que é também ofensivo do homenageado- que termine com o lançar do vaso para trás das costas, numa tentativa de evitar a poluição inerente a um contacto com a morte. Com as suas perguntas e reflexões, Electra cumpre a função de sublinhar a anormalidade de um ritual, à superfície comum, mas carregado de inconsistências intoleráveis. Mais conhecedora das mulheres do que Orestes, a jovem pode repetir os sentimentos que a unem às companheiras, ódio e temor ( $\tilde{z} \chi \theta \circ, \phi \dot{\beta} \beta \omega, 101-102)$. Com o reconhecimento de que homens livres e escravos estão sujeitos a igual destino (103-104), ${ }^{16}$ a filha de Agamémnon reduz hierarquias para acentuar cumplicidades; é, por isso, como um grupo coeso que todas as mulheres -coro e personagem- se preparam 
para dar início ao cerimonial; mas este é também o momento de marcar o ascendente do coro, de mulheres cuja maturidade e experiência tem agora a oportunidade de se evidenciar. ${ }^{17}$

É, enfim, sob a condução do coro, que o ritual se executa. Poucas palavras do corifeu bastam para produzir

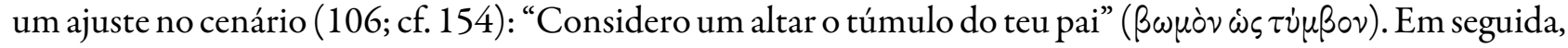
porque não é fácil o diálogo entre vivos e mortos, incomensurável como é a distância que os separa, há que elevar a voz para tornar audível ao além a prece dos que ainda habitam a terra $(109,152)$. Definidos o contexto e a forma de actuar, resta estabelecer o conteúdo: apelar ao morto em favor dos amigos e não são muitos os que restam ao Atrida, a filha, as servas do palácio e Orestes, o exilado -aqui habilmente lembrado como um aliado prestes a comparecer como participante no ritual (115); e suscitar o ódio contra os inimigos, no apelo à vinda de um vingador capaz de pagar violência com violência (117-121). É, assim, ao coro que cabe enunciar a que é a grande legenda de Coéforas: ama os amigos e odeia os inimigos (123). Está concluída a sequência dramática de monólogo de abertura dito por Orestes, párodo e esticomitia entre o coro e Electra, que conduz à execução do kommós, com vista ao estabelecimento do impulso de vingança em pleno ritual.

Electra está finalmente capaz de pronunciar a prece, de acordo com os conselhos das mulheres (124-151), e o coro um péan, reproduzindo a sequência convencional da prece e do lamento colectivo (152-163). As palavras ditas, no entanto, produzem uma estranha dissonância; está em marcha a metamorfose de um ritual de apaziguamento em canto de maldição e vingança; ${ }^{18}$ que os lamentos destruam o efeito apotropaico das “abomináveis libações" (155-156) e enfim, seja ele quem seja, chegue o vingador. A resposta à invocação é imediata, naturalmente envolvendo os deuses e a alma do Atrida ("a terra já bebeu as libações e o meu pai as recebeu”, reconhece Electra, 164), mas sobretudo movendo a aparição de um Orestes afinal testemunha do apelo feminino. Está iminente o reconhecimento; e apesar de esse ser um episódio confinado aos dois irmãos, o coro não deixa de colaborar na emoção do momento com uma carga de reacções opostas: de medo (167) perante o achado da madeixa de cabelo que Electra anuncia; de surpresa, pelo que há de obscuro numa oferenda que só os parentes - neste caso inimigos-podem garantir (173, 189-190); e se Electra parece assumir agora uma posição de privilégio por ter sido ela a descobrir um testemunho que irá reorientar o ritual, são, no entanto, as mulheres do coro as primeiras a admitir a hipótese de os cabelos serem de Orestes (177) e a sofrer à ideia da impossibilidade de que o filho de Agamémnon possa pisar chão pátrio (181-182).

Consumado o reconhecimento, abre-se diante dos vingadores a hora de agir. Seria, porém, de uma brutalidade cruel ou mesmo ilegítima a execução imediata de uma retribuição que afinal é matricídio. Por isso o poeta elabora o célebre kommós, um longo canto de mobilização e argumentação no sentido de tornar exigível, piedoso e justificável o homicídio extremo que se avizinha. ${ }^{19}$ É seu principal objectivo mobilizar a participação de Agamémnon na vingança, depois de invocados os deuses. Sem deixar de ser matricida, Orestes cumpre mesmo assim a função religiosa, cívica e doméstica que a ordem cósmica dele espera.

Cabe ao coro recordar, nos anapestos que entoa antes da primeira tríade, ${ }^{20}$ as exigências da Justiça e repetir o código de vingança de que ela é o garante (306-314): ${ }^{21}$ que toda a palavra de ira seja paga com outra palavra de ira, e que todo o golpe sangrento seja punido com outro golpe sangrento. Amplia assim para termos gerais aquilo que os dois jovens tinham traduzido em razóes pessoais e insiste na filosofia geral da peça. Estabelecido o princípio, o coro irá pontuar cada intervenção dos dois irmãos com palavras de incentivo, sublinhando a execução de um castigo em que as várias facetas do crime cometido vão sendo sucessivamente enumeradas. Ao apelo que Orestes dirige ao pai, as mulheres opõem a garantia de que os mortos não se extinguem e de que a sua intervenção é inevitável (324-331); as suas palavras são neste caso valorativas do parentesco, como um

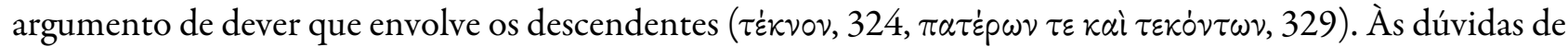
Electra quanto ao futuro e ao termo dos sofrimentos que a afligem, também causados pela ausência do pai, o coro responde com o optimismo de ver um treno -o que agora fala de morte- substituído por um péan de vitória (340-345). ${ }^{22}$ Por seu lado Orestes conduz a prece para o lado heróico, a contento com valores masculinos; o desejo por ele expresso de que o pai tivesse morrido em Tróia, sugere que o coro louve as 
qualidades de rei e militar que foram as de Agamémnon, agora já não apenas um pai, a quem é devida a homenagem dos seus herdeiros, mas o general vitorioso e rei legítimo, ao contrário dos usurpadores à frente do destino do povo (354-362). E quando, por fim, Orestes assume plenamente a necessidade do matricídio, ${ }^{23}$ o coro confessa, com desassombro, o seu ódio a Clitemnestra (386-392). Os filhos de Agamémnon passam então a ocupar o lugar das vítimas, centrando sobre si mesmos as ofensas resultantes da ambição ilegítima da rainha. Com o acumular de culpas, vai crescendo também a ira e subindo o tom que a expressa; o grito, que já não é fúnebre mas de protesto, torna-se mais agudo (386-388), a discrição dá lugar à confissão da raiva que as servas têm alimentado, oculta pelo medo. Ódio, cólera, raiva, são brados que se lançam sem pejo, num crescendo que envolve todos os fiéis a Agamémnon, que passaram agora a ser sobretudo os inimigos de Clitemnestra. É Electra quem reorienta a atenção do plano pessoal para o da exigência divina, sobrepondo a quaisquer outros motivos aqueles que Zeus e os deuses infernais impóem (394-399); e, em uníssono, o coro evoca as Erínias (400-404) e a lei que faz delas as administradoras de uma vingança infalível e automática, a reclamarem dos homens a satisfação da sua sede sanguinária; a colaboração dos deuses ofendidos vem, portanto, aderir aos motivos humanos; e todo o excesso que eles possam conter fica legitimado pela exigência da lei.

Enunciadas as razões e mobilizados os vingadores, a hora de agir aproxima-se, provocando a expressão dos diversos estados de espírito, que individualizam de alguma forma os envolvidos; Orestes, apesar de firme na sua decisão, tem ainda, a abrir a quarta tríade, palavras de aflição perante um acto que põe a nu o destino funesto a que se sente condenado como herdeiro dos Atridas (405-409); a interrogação final que dirige ao deus supremo - “para onde nos poderemos voltar, ó Zeus?”- é bem o desabafo de um horror invencível perante o matricídio. Como espelho da fragilidade confessada pelo vingador, o coro oscila entre o sobressalto de um recuo e o desejo de que uma disposição mais viril possa fazer renascer a esperança (410-417); anseio que merece a adesão de Electra, que se declara, de forma desassombrada, herdeira da disposição violenta da mãe (418-420). Parece, por fim, que estes são depoimentos determinantes para calar os escrúpulos daquele que terá de ser, por força da própria natureza, a mão da vingança, Orestes; ${ }^{24}$ perante a exaltação do coro, que redobra o tom dos lamentos (423-428), ${ }^{25}$ e diante do ódio cada vez mais afirmativo de Electra em relação "à mãe impudente" (429-433), o filho de Agamémnon assume no seu sentido pleno o acto a que se vê compelido (438): “Que eu a mate e morra a seguir!”. Como que empolgadas pelo rumo decisivo que as diversas vontades vão tomando, as cativas, perante um Orestes agora silencioso, passam a acentuar os detalhes de violência com que o crime de Clitemnestra foi praticado, legitimando igual medida na resposta (439-443); ao mesmo tempo que Electra desdobra, em pormenores mais impressivos, as ofensas de que também ela foi objecto - "afastada, humilhada, aviltada", tratada como "um cão malfazejo", vivendo mergulhada em soluços nas sombras do palácio (444-450). Numa palavra final, o coro impõe a cólera como a mestra a ditar a Orestes, a partir deste momento, a necessária actuação. É nessa raiva partilhada que, enfim, todas as vontades e propósitos se harmonizam (como um "colectivo revoltado", 458) numa prece comum pelo bom sucesso da vingança, um gesto que uma casa maldita terá de encontrar em si mesma como remédio para tantos males. Depois de incentivar a uma ira estimulante, o coro marca o apaziguamento que a decisão tomada proporciona. É sua a última palavra, que assinala o momento em que à consciencialização de tudo o que está em causa se vai suceder a acção (512-513): "Uma vez que estás determinado a agir, vai em frente, põe à prova o destino!".

Mais do que mobilizadoras de vontades, as cativas assumem-se como cúmplices do golpe vingativo, com conselhos práticos que ajudam ao bom êxito da acção. O diálogo que passa a envolvê-las directamente com o executor da vingança coloca num outro patamar a sua intervenção. Foram testemunhas do sonho e do temor que se apossou de Clitemnestra e motivou o ritual apaziguador (523-525); podem, por isso, relatar a mensagem de que ele foi transmissor e prever, a partir da clareza dos sinais que deixou, o desfecho positivo para Orestes (526-539). Dada esta garantia, a estratégia prática deixam-na, enfim, ao cuidado do protagonista da tremenda missão (552-553). 


\section{O CORO COMENTADOR}

Tomada a decisão, a intervenção do coro de certo modo reorienta-se; a partir daí, a sua função passa a ser sobretudo, como se foi tornando convencional na tragédia, a de testemunha e comentador.

O tempo durante o qual Orestes e Pílades se dirigem ao palácio para dar início à vingança é preenchido pelo coro com o I Estásimo (585-651), um canto que oportunamente se abre à ideia da punição do mal e, em consequência, à morte de Clitemnestra. Este é um ponto de fronteira entre uma primeira parte de Coéforas, a da mobilização dos vingadores e dos seus aliados do além, e uma segunda que, com o palácio por cenário, irá dar satisfação a esse propósito. ${ }^{26}$ É, portanto, para um princípio geral que as reflexões do coro convidam os espectadores. Os monstros, as catástrofes, os furacões são inerentes à própria natureza e inimigos incontornáveis para os mortais; ou seja, o Homem está condenado, em função da própria vivência cósmica, a enfrentar o medo e a dor. Mas sobretudo ousado ( ferocidade e funesto nas suas consequências é o próprio ser humano, lido a partir da arrogância masculina,

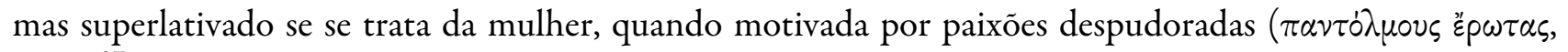
597), ${ }^{27}$ que põem em causa a segurança das casas e da sociedade, desrespeitando o seu papel natural e hostilizando os seus parceiros. Estas "são mulheres que se revelam portadoras de morte em vez de dadoras de vida, mulheres que arruínam a sua função natural e social ao ameaçar destruir os fundamentos da vida familiar e política”. ${ }^{28}$ E seguindo uma convenção bem conhecida, ${ }^{29}$ o coro passa a ilustrar as suas afirmações com exemplos míticos de comportamentos que reflectem rupturas familiares: o de Alteia, causadora da morte do filho, Meléagro, ao incendiar um tição de que a vida do jovem dependia, penalizando-o assim pela morte dos seus irmãos; ${ }^{30}$ e o da "sangrenta Cila" que, seduzida por Minos, arrancou da cabeça do pai o cabelo vermelho para ele uma condição de vida; sob o efeito da paixão, condenava Niso e a cidade de Mégara à submissão ao invasor. É então oportuno afunilar a reflexão para o episódio da peça e colocar "a esposa detestável” (624-625) na mesma linha dos exemplos evocados; também ela teve artes de eliminar um rei e campeão que aos seus iguais causava temor. ${ }^{31} \mathrm{E}$ por último, pela sua dimensão colectiva ou mesmo cósmica, o homicídio dos maridos levado a cabo pelo ciúme das mulheres de Lemnos ficou como paradigma do desprezo que merecem aqueles(as) que agem em contrário das determinações divinas, dessa forma ameaçando a própria sobrevivência da Humanidade. ${ }^{32}$ Em conclusão, o coro regressa ao tema da Justiça e do rigor com que ela exerce, sobre os que prevaricam, o seu papel de vingadora. Aos tópicos já antes aludidos, que essencialmente valorizavam as distorções dentro do género humano, vêm associar-se, por fim, os deuses como árbitros superiores. Reafirmado o empenho na vingança, o coro passa a pontuar cada momento na evolução do processo com protestos de cumplicidade. Pela voz da Corifeia primeiro, logo desenvolvida por um canto colectivo, o espectador é conduzido através do sentido subjacente aos acontecimentos. Antes ainda da próxima intervenção lírica, a Corifeia (719-733), perante a entrada no palácio do matador e da sua vítima, dirige às companheiras, em ritmo anapéstico, um apelo de mobilização. Não lhes restam mais armas do que a voz, mas não negam a Orestes este apoio. Assim se anuncia o envolvimento que o coro não deixará de ter em todo o processo que se segue, agora que o protagonismo pertence a quem conduz a acção: o de invocar os deuses, tendo em atenção aqueles cuja força maior oportunidade pode ter. A própria variação nos destinatários da prece constitui a legenda oportuna para a tónica de cada momento. E neste ponto de partida, em que se trata de iludir as vítimas para as tornar vulneráveis, o coro apela à terra e aos poderes subterrâneos, à Persuasão, para que assegure a eficácia do engano de que depende o golpe de Orestes; e por fim a Hermes Ctónico, como garante das mortes iminentes. ${ }^{33}$

O mesmo tom de apelo aos deuses constitui o efeito geral do II Estásimo (783-837), entoado durante a ida da Ama de Orestes em busca de Egisto, o primeiro dos dois usurpadores a ser aniquilado. Ainda que muito fragmentária, o que resta desta intervenção coral permite mesmo assim compreender-lhe o objectivo e a reorientação face aos apelos já antes proferidos. ${ }^{34}$ Dos preparativos, o coro foca-se agora nos resultados; 
por isso é para a casa dos Atridas que a sua atenção se dirige. Zeus ocupa, na primeira tríade, posição destacada como divindade suprema e detentora da Justiça; e usando como argumento a generosidade futura do vencedor devida ao pai dos deuses, o coro coloca todo o seu empenho no palácio e no jovem príncipe que lhe prepara a libertação. Por isso, naturalmente o apelo seguinte vai para as divindades do lar (800-802), protectoras do património contra os que são os seus usurpadores, mas sobretudo neutralizadoras de uma maldição que se prolonga por gerações. Segue-se-lhes Apolo (807-811), para que contagie da luminosidade do seu santuário a mansão sombria dos Atridas. E, por fim, de novo Hermes infernal (812-818), ao mesmo tempo inspirador do dolo e regulador da fronteira entre vida e morte. Animadas pelo que lhes parece garantido -a protecção divina-, as mulheres sonham já com os cantos de júbilo que hão-de celebrar a vitória. Não sem que, no entanto, as suas últimas palavras vão para a dificuldade extrema do que está em causa, um matricídio. As servas podem imaginar o apelo que a vítima - a mãe- não deixará de fazer ao vínculo sagrado da maternidade; ouvem, por antecipação, o brado - “meu filho!”, 829-, que Clitemnestra vai usar como sua única arma. E prevendo também o escrúpulo de Orestes -já patente em todo o kommós-, deixam ainda uma palavra de estímulo para que não recue, no momento derradeiro. Egisto não merece ao coro qualquer menção, porque o que importa de facto assinalar é o clímax da vingança, o matricídio.

A vinda de Egisto e a sua entrada no palácio representa a iminência do primeiro golpe. E como que chamando a si os temores e o perigo a que o vingador se verá sujeito, a Corifeia (855-868) substitui certezas por interrogações, como se as dúvidas que atormentaram no kommósa filha de Agamémnon e que as servas tentaram calar (87-88) as afectassem agora também (855-858): "Zeus, ó Zeus, o que dizer? Como heide começar a minha prece, o meu apelo aos deuses? E, com sensatez, como terminá-la e dizer o que é conveniente?" O que as atormenta é sobretudo a dúvida pelo resultado decisivo de um golpe arriscado: ou a ruína definitiva para aquela casa, ou o acesso a um novo caminho de prosperidade e libertação. Por isso, depois de ter 'parafraseado' Electra, as últimas palavras da Corifeia vão para Orestes, a quem a missão que enfrenta não permite recuo, apesar dos riscos imensos que comporta. $\mathrm{O}$ coro parece reviver, em cada nova etapa concreta, os temores e emoções que o kommós adiantava ainda em abstracto.

O III Estásimo (935-972) antecede o momento fulcral da peça, aquele em que, depois de um debate derradeiro entre mãe e filho, ambos entram no palácio para que o matricídio se consume. Uma palavra de comiseração por ambos (931) parece trazer alguma ponderação aos protestos de ódio contra Clitemnestra, que as servas tinham antes tornado manifesto. Apesar de todos os motivos e agravos, matricídio é matricídio e, por um momento, o coro abre espaço à compreensão humana que um tal crime exige. Mas é fugaz esse arrepio. Porque já o seu canto passa a ser de alegria e celebração da vinda, sempre reclamada, da vingança. Em nome da libertação do palácio, o crime que se prepara é duplo (938, 944-945), pela eliminação sucessiva dos dois usurpadores. E o coro escuda-se na ideia do 'duplo', sem mencionar especificamente o acto que agora está iminente, o matricídio. Nas suas palavras, o gesto à beira de consumar-se não distingue os dois usurpadores; é, portanto, antes de mais político. Nele, as mulheres incluem de seguida a participação dos deuses (941), advogando-lhe a legitimidade; é a mão da Justiça que guia Orestes (949-952), enquanto Apolo, o mandante da vingança, encontra, mesmo se tarde, satisfação (953-956); logo, o acto de Orestes é também patrocinado pelos deuses. É assim chegada a hora da revelação de uma Justiça segura e infalível, de que o palácio dos Atridas se converte em paradigma. E silenciado o horror que ele também comporta... é ainda o vigor da justiça a dominar, embora esta omissão prometa o difícil momento do remorso, passada a euforia da vitória.

E esse surge, quando Orestes retorna erguendo a espada da vingança diante dos cadáveres das suas vítimas. Mais do que de sucesso, o seu discurso é de justificação. E o resultado -reconhece-o o matricida- é uma vitória amarga porque também provocadora de uma mancha terrível (1016-1017). A esta apreensão que abala o vingador, o coro responde com igual abatimento (1018-1020); ao que se encarava como o cumprimento do dever sucede-se agora o reconhecimento de como a vida humana não é isenta de percalços. E quando as Erínias surgem diante do espírito atormentado de Orestes, o coro, em diálogo com o matricida, contribui para produzir uma transição do que era determinação e optimismo e terminou em apreensão e terror (1049-1062). 
Só agora parece haver uma tomada de consciência das sequelas de tal crime, causador não de luminosidade e paz, mas de poluição e remorso.

São, por fim, do coro as últimas palavras da peça, para aconselhar ao homicida o caminho de Delfos, onde Apolo - sua última esperança- o poderá purificar. Há que reconhecer, afinal, que o que parecia uma promessa de luz não passou de um elo mais na cadeia de sombras de que a casa dos Atridas, de geração em geração, passou a ser cenário. O que parecia um desfecho volta a ser, surpreendentemente, um começo.

\section{Conclusão}

O coro de Coéforas cumpre bem a função de personagem que Aristóteles havia de considerar como marca de qualidade de um grupo coral. A sua actuação obedece, ao longo da peça, a vários ritmos, numa articulação equilibrada com a dos vingadores; enquanto a hesitação inicial dos filhos de Agamémnon abre espaço à autoridade e determinação das servas, à medida que a execução da vingança passa a depender da iniciativa dos jovens, o papel do coro vai tendendo para o de um comentador ou conselheiro. Há, mesmo assim, que lhe reconhecer sempre um papel activo, que pode até -com as orientações que dá à Ama e a Egisto- facilitar as condições para que o golpe de Orestes tenha sucesso.

Reconhecendo-lhe a identidade e predominância, tem cabimento a pergunta que McCall (2005, p. 22) formula: “porque terá Ésquilo criado um papel coral tão díspar com a identidade do coro?”. Mas talvez um certo anonimato em relação à sua proveniência como cativas e a sua qualidade exterior à família que servem as deixe mais livres, na leitura e intervenção que têm nos acontecimentos.

De companheiras de Electra, as mulheres do coro vão passando a cúmplices de Orestes, a partir do momento em que o dever faz dele o matricida. Empolgam-se com a necessidade da vingança, ainda que omitam, como num voluntário esquecimento, a menção expressa a que é uma mãe o alvo da desforra. Por esta omissão, em cena e no auditório as consequências do matricídio aparecem como algo em certa medida inesperado, e impeditivo do efeito pacificador que a vingança parecia prometer. Afinal a morte de Clitemnestra não se consumou como o remate de uma cadeia de crimes, mas simplesmente como um elo mais numa sucessão de penas; a maldição dos Atridas continua.

\section{REFERÊNCIAS}

Auer, J. (2006). The Aeschylean Electra. GRBS 46 (3), 249-273.

Bruschi, L. (2005). Chi a paura della giustizia? Aesch. Choeph. 55-65. Hermes 133 (2), 139-162.

Burkert, W. (1985). Greek Religion. Archaic and Classic. Trad. ingl. Oxford: Basil Blackwell.

Conacher, D. J. (1974). Interaction between chorus and characters in the Oresteia. AJPh 95 (4), 323-43.

Garvie, A. F. (1986). Aeschylus. Choephori. Oxford: Clarendon Press. Edição usada

Kurtz, D. C. y Boardman, J. (1971). Greek burial customs. London: Thames and Hudson.

Lebeck, A. (2007). The first stasimon of Aeschylus' Choephori: Myth and mirror image. En M. Lloyd (Ed.), Oxford Readings in Classical Studies. Aeschylus (pp. 316-22). Oxford: University Press.

Lynch, G. O. (2005). 'Why do your eyes not run like a river?' Ritual tears in ancient and modern Greek funerary tradition. En K. C. Patton y J. S. Hawley (Eds.), Holy tears. Weeping in the religious imagination (pp. 67-82). Princeton and Oxford: Princeton University Press.

McCall, M. (2005). The chorus of Aechylus' Choephori. En M. Griffith y D. J. Mastronarde (Eds.), Cabinet of the Muses (pp. 17-30). Berkeley and Los Angeles: Univ. of California.

Podlecki, A. J. (1972). The Aeschylean chorus as dramatic persona. En Studi Classici in onore de Quinto Cataudella. I (pp. 187-204). Catania: Università de Catania.

Pulleyn, S. (1997). Prayer in Greek religion. Oxford: Clarendon Press. 
Sevieri, R. (2004). Il mondo alla rovescia nel I stasimo delle Coefore di Eschilo. SIFC 97 (2), 158-88.

Stears, K. (1998). Death becomes her. Gender and Athenian death ritual. En S. Blundell y M. Williamson (Eds.), The sacred and the feminine in ancient Greece (pp. 113-27). London and New York: Routledge.

Stinton, T. C. W. (1979). The first stasimon of Aeschylus' Choephori. CQ29 (2), 252-62.

Taplin, O. (1977). The stagecraft of Aeschylus. The dramatic use of exits and entrances in Greek Tragedy. Oxford: Clarendon Press.

Tarkow, T. A. (1979). Electra's role in the opening scene of the Choephoroi. Eranos 77 (1), 11-21.

\section{NoTAS}

1 Cuja chegada, é certo, tinha sido prevista em Agamémnon, primeiro por Cassandra (1280-1285) e, já cometido o homicídio, pelo coro (1646-1648, 1667).

2 Eurípides, Helena 825-830, deixa claro como a súplica compete sobretudo a mulheres.

3 A edição citada no artigo é Garvie (1986).

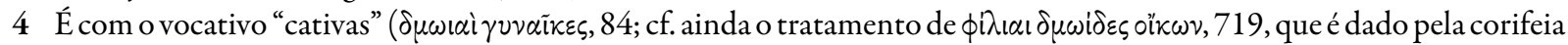

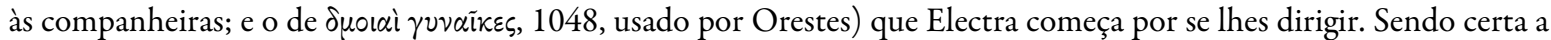
sua identidade como cativas, continua mesmo assim polémico se se trata de cativas troianas (vide scholium Choephoroe 75), ou simplesmente de quaisquer cativas (vide McCall, 2005, pp. 17-21). Mas é em harmonia com esse estatuto que a sua actuação se desenvolve; embora Electra tente eliminar hierarquias para criar com as companheiras uma maior cumplicidade (103-104), o coro não deixa de sentir como "ordens" ( $\kappa \varepsilon \lambda \varepsilon \dot{\varepsilon} \varepsilon \iota, 107)$ os seus apelos. Começa por assumir, portanto, dentro da sua condição, uma atitude submissa primeiro em relação a Clitemnestra e depois a Electra.

5 Burkert (1985, p. 70) recorda que o derramamento de líquidos -ou libação- era um acto sagrado dos mais comuns. E acrescenta que a designação de $\chi 0$ ท provém do tipo de vaso usado num ritual em particular vinculado à homenagem dos mortos e dos deuses ctónicos. Os líquidos que a terra absorve -vinho, água, azeite, mel- destinam-se a satisfazer os deuses e a pacificar e nutrir os defuntos.

6 Lynch (2005, p. 68) no entanto, chama a atenção para o facto de soluços e lágrimas, que acompanham gestos emotivos, não significarem, como para nós, manifestações de uma emotividade espontânea. Trata-se de obedecer a uma convenção própria de contextos de morte, sem o que os rituais podem parecer incompletos ou sem sentido. O lamento segue uma configuração bem estabelecida, em que os sentimentos pessoais são amplificados e expressos de acordo com princípios socialmente definidos. O mesmo comentador toma como testemunho a censura que Electra (Coéforas 429-433) dirige à mãe por ter procedido ao sepultamento de Agamémnon sem o cumprimento das regras, "em silêncio e sem lágrimas piedosas". Em contrapartida, ao longo do kommós que precede o golpe vingativo, o coro irá repetindo em crescendo estas manifestações; e as próprias mulheres vão reconhecer que alguma exuberância que se vai apossando delas segue um modelo inspirado no Oriente, o dos "Medos e das carpideiras císsias" (423-424). Importa recordar que a exuberância destas manifestações fúnebres atingiu tais excessos, que Sólon sentiu necessidade de legislar sobre a proibição de algumas atitudes (cf. Plutarco, Sólon 21, Cícero, Sobre as leis 2.59, 64).

7 Garvie (1986, p. 59) especula sobre os motivos deste medo: ou porque o coro tema atrair sobre si as iras do além ao dizer palavras que não são aceitáveis - as que Clitemnestra lhe recomendou-, ou, pelo contrário, receie que o poder das palavras seja tal que promova uma reconciliação entre o além e a esposa assassina. Cf. ainda Bruschi, 2005, pp. 139-162.

8 Ou seja, apesar de haver um calendário estabelecido de homenagens ao defunto (no nono dia, ou um ano depois da morte; cf. Kurtz y Boardman, 1971, pp. 147-8), não parece que a celebração fúnebre de Coéforas lhe obedeça (ainda que o estado fragmentário do monólogo de abertura possa sugerir a possibilidade de aí ter sido estabelecido um tempo decorrido sobre a morte de Agamémnon). O ritual que o coro executa parece mais um acto de urgência, exigido por um sonho denunciador do desagrado dos que habitam o Hades. Sobre as questões relacionadas com o culto dos mortos, cf. ainda Pulleyn, 1997, pp. 116-131.

9 Ao discutir a relevância social que a participação em rituais fúnebres representava para as mulheres, Stears, 1998, p. 125 admite que o encontro de grupos femininos junto aos túmulos lhes propiciava espaços de convívio e de intervenção; "pode parecer-nos que estes actos não passam de conversa e mexerico, mas não serão eles maneiras indirectas de obter conhecimento e assim uma forma de poder?"

10 Sobre os gritos rituais, informa Burkert (1985, p. 74): a ỏ $\lambda \circ \gamma v \gamma \eta \dot{~ e ́ ~ u m a ~ i n v o c a c ̧ a ̃ o ~ m a i s ~ e l e m e n t a r, ~ e x p r e s s a ~ p o r ~ s o n s ~}$ inarticulados e altamente emotivos. Por sua vez o péan está associado com o culto de Apolo, um canto cujo nome reproduz um grito, ie ie paian, destinado a afastar o mal e a celebrar a vitória.

11 Podlecki (1972, p. 199) considera ser a função "dramática” a mais relevante das desempenhadas por este coro, manifestada, antes de mais, pela cumplicidade expressa entre as servas e Electra no ódio por Clitemnestra. Mais adiante, 
já em plena acção de vingança, o coro interfere directamente no evoluir dos acontecimentos: ao persuadir a Ama a alterar a ordem recebida da rainha para fazer Egisto voltar ao palácio sem guarda (770-773); e, quando Egisto aparece, apressá-lo a entrar no palácio para ser morto (848-850). Esta agilidade representa, para Podlecki, um progresso dentro da utilização dos coros por Ésquilo. Por sua vez Auer (2006, p. 251) é peremptória ao afirmar sobre a força dramática do kommós de Coéforas: "este é o canto lírico mais longo e mais complexo que sobreviveu da tragédia grega, e patrocina a fusão mais íntima entre actores e coro".

12 Burkert (1985, p. 73) sublinha a importância do rigor do que há a dizer neste contexto; evitar qualquer palavra nefasta (blasphemia) e empenhar-se numa linguagem correcta (euphemia). Esta mesma sensibilidade ao rigor da palavra, sobretudo quando se trata de rituais de enorme alcance para quem os executa, é também valorizada por Platão (Leis 688b, 801a-b).

13 Esta hesitação de Electra sobre as palavras justas coloca dúvidas sobre o perfil da jovem em Ésquilo e sobre a relação de maior ou menor dependência em relação às mulheres do coro; sobre o assunto, cf. Auer (2006), que discute as várias interpretações e assume a defesa de uma Electra mais determinada e madura.

$14 \operatorname{Auer}(2006$, p. 254) valoriza o estilo ritual e retórico destas perguntas, acentuando-lhes o lado mais convencional e menos espontâneo. Pulleyn (1997, pp. 132-155) sintetiza o modelo padrão da prece com as componentes seguintes: invocação (que tende a repetir, em vocativo, o nome da entidade a quem a prece é dirigida, e a acumular verbos sugestivos de 'ouvir' e 'vir'); o argumento (a substância do pedido e os motivos para a sua concessão) e a súplica (abundante em fórmulas que pretendem cativar a boa vontade de quem é interpelado).

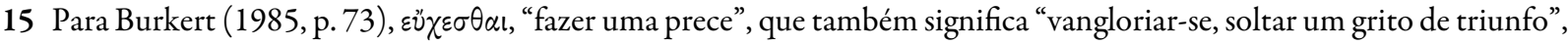
é sobretudo uma forma de chamar a atenção sobre quem a pronuncia, incluindo nela o voto sobre o que se pretende obter (cf. Coéforas 98-99, 109). Implicitamente, a prece inclui o reconhecimento do poder que a morte confere a quem habita já o Hades. A comunicação entre vivos e mortos é algo que as cenas de morte representadas nos lécitos deixam sempre patente.

16 Tarkow (1979, p. 12) justifica de certa forma esta proximidade entre Electra e as cativas pelo facto de, nos últimos anos de vida, a princesa ter tido no palácio um estatuto semelhante ao de uma escrava (cf. 135).

17 Auer (2006, pp. 257-258) equilibra a relação coro/ Electra de outra forma, entendendo que a figura da princesa tem uma maior determinação do que aquela que habitualmente lhe é concedida. Considera então que se trata mais, para Electra, de ganhar a confiança do coro para um plano de vingança que já lhe baila no espírito, e de lhe manipular as emoçóes, do que de se submeter, por inocência ou imaturidade, aos seus conselhos.

$18 \mathrm{Ou}$, nas palavras de Garvie (1986, p. 82): "situado no meio deste longo episódio, este passo separa a prece e libações de Electra do reconhecimento que se segue. Ao mesmo tempo, marca o desenvolvimento do párodo para o kommós, em que o desejo de vingança passa a ser claramente expresso".

19 Cf. a definição que Aristóteles (Poética 1452b 24) dá de kommós como um treno entoado em conjunto pelo coro e actores. É bem conhecida a controvérsia interpretativa que rodeia este kommós: para uns trata-se de levar Orestes a ultrapassar a repulsa pelo matricídio; ou, para outros, já adquirida a determinação do vingador desde o início da peça, de mobilizar a cumplicidade do espírito de Agamémnon e dos deuses ctónicos; uma síntese desta controvérsia é dada por Garvie (1986, pp. 122-125). Fora de dúvida está a ideia de que Ésquilo fazia uso de um modelo de canto conhecido do público como próprio de rituais fúnebres.

20 A primeira parte do kommós estrutura-se em quatro tríades, cada uma delas comportando uma estrofe entoada por Orestes, seguida de uma intervenção do coro antes da antístrofe de Electra; separa as sucessivas tríades uma intervenção coral em anapestos.

21 Podlecki (1972, pp. 198-199) regista que é ao coro que compete repetir regras, como as que se relacionam com a justiça, válidas para toda a trilogia e já antes enunciadas em Agamémnon; é o caso de "quem comete um crime paga" (313, cf. Agamémnon 1564).

22 Este é um comentário expresso em termos da convenção lírica, fazendo corresponder dor e alegria aos cantos que melhor os podem traduzir. Para Garvie (1986, pp. 81-82), o lamento corresponde ao passado e o péan à vitória que se deseja para o futuro, em defesa da memória de Agamémnon e em confronto com os usurpadores; "a combinação das duas ideias é típica da trilogia, em que a desejada vitória se converte em motivo de lamento”.

23 Porque reúne adeptos a ideia de que a sua determinação à vingança existia desde as primeiras palavras que lhe ouvimos, embora a consciencialização de que é um matricídio o que lhe toca cometer pareça consolidar-se com o tempo.

24 Entramos aqui numa nova fase do kommós (423-455), moldada num modelo diverso de estrofes e antístrofes, sem intervenções anapésticas, em que o coro vai respondendo aos seus dois interlocutores.

25 Auer (2006, pp. 269-270) não deixa de registar que a ordem das intervenções seguida até aqui no kommós se altera; é o coro que toma a dianteira, seguido por Electra e Orestes; justifica a mesma autora: "são as mulheres que passam a comandar esta secção narrativa do kommós, em que a função de testemunhar e relembrar o mythos da família, por Electra e o coro, se dirige a Orestes. É sobretudo aqui que vemos o poder impressivo e a decisão do coro”. 
26 Sevieri (2004, p. 158) valoriza a posição estratégica deste canto no plano geral da trilogia, o que faz dele o ponto central do desenvolvimento pleno da Oresteia; cf. Lebeck, 2007, p. 316. Do passado -dado a conhecer em Agamémnon e recordado como motivo central do kommós-, vai passar-se agora ao futuro, com a tentativa de extirpar as sombras do palácio do Atrida. Clitemnestra está prestes a passar de carrasco a vítima. Com este canto -e com a mudança de cenário que ele acompanha- produz-se o que Taplin, (1977, pp. 338-339) designa por “refocagem”.

27 A ideia de que a cedência ao instinto é própria das fêmeas em geral, da mulher como dos animais (599-601), põe-lhe em causa o bom senso, parecendo natural um comportamento exacerbado. Que esta condenação seja proferida por vozes femininas só se justifica pelo ódio que o coro exprime em relação a Clitemnestra.

28 Sevieri, 2004, p. 165.

29 Ainda que rara no teatro conservado de Ésquilo.

30 Cf. Baquílides 5.93 sqq.

31 Segundo Sevieri (2004, p. 160), a comparação entre o comportamento de Clitemnestra e o destas mulheres insensatas do mito tende a escamotear o peso do matricídio e a colocar a tónica sobre a culpabilidade da mãe de Orestes.

32 Sevieri (2004, p. 173) identifica o efeito de crescendo conseguido pelos vários exemplos invocados: "há uma evidente progressão lógica, da história de Alteia (uma mãe que mata o filho), para a de Cila (uma filha que causa a morte do pai), para culminar com os exemplos de Clitemnestra (...) e das mulheres de Lemnos, ou seja, mulheres que matam os maridos". Como mãe uma delas, outra filha, outras esposas, no conjunto os exemplos cobrem todas as funções que compõem o curriculum feminino. Por sua vez Stinton (1979, p. 256) tinha estabelecido um outro nexo entre os diversos exemplos, sugerindo que o sentido de todos eles converge em Clitemnestra: "ela actua, como Alteia, para vingar um parente muito próximo, como Cila, devido a um amor ilícito, e como as mulheres de Lemnos, por ciúme em relação à amante do marido".

33 Como bem observa Garvie (1986, p. 240), a nossa atenção é atraída para o palácio sem nos permitir esquecer o túmulo, o que promove a articulação das duas partes da peça.

34 Garvie (1986, p. 255) identifica o modelo deste canto como composto por três pares de estrofes, "sugerindo três tríades, embora de um modelo muito menos complicado do que o do kommós”. O III Estásimo, por sua vez, irá repetir o modelo. 